\section{OF GRIZZLIES AND MAN: WATCHING WERNER HERZOG'S GRIZZLY MAN THROUGH AN ECOCRITICAL LENS ${ }^{1}$}

\section{Phacharawan Boonpromkul $^{2}$}

บทคัดย่อ

ภาพยนตร์สารคดีเรื่อง กริซซลี แมน (2005) โดย ผู้กำกับ เวอร์เนอร์ เฮอร์ทซอค เป็นหนึ่งใน ภาพยนตร์ที่นักวิจารณ์วรรณกรรมสิ่งแวดล้อมให้ ความสนใจ เนื่องจากมีเนื้อหาเกี่ยวข้องกับสัตว์ป่า ธรรมชาติ การอนุรักษ์สัตว์ป่า และความสัมพันธ์ ระหว่างสายพันธุ์โดยตรง บทความนี้วิเคราะห์ สารคดีเรื่องนี้ในฐานะภาพยนตร์เชิงนิเวศใน 5 ประเด็น คือ การใช้ประเภทภาพยนตร์สารคดีใน การถ่ายทอดภาพสัตว์ป่า ความคลุมเครือและข้อ โต้แย้งเกี่ยวกับ ทิม โมธี เทรดเวลล์ นักอนุรักษ์สัตว์ และเจ้าของต้นฉบับภาพยนตร์ผู้ล่วงลับ หมีกริซซลี กับตำแหน่งฉากหลัง การให้เสียงและการลำดับเรื่อง โดยผู้กำกับ เฮอร์ทซอค และฉากจบของภาพยนตร์ การศึกษาวิเคราะห์ประเด็นทั้งห้านี้จะช่วยให้ผู้ชม เข้าใจเนื้อหาของภาพยนตร์และการวิจารณ์

\footnotetext{
1 อ่านภาพยนตร์สารคดีเรื่อง กริซซลี แมน ผ่าน แนวคิดนิเวศวิจารณ์

2 (พชรวรรณ บุญพร้อมกุล) Lecturer, Department of English Language and Literature, Faculty of Liberal Arts, Thammasat University, Thailand
}

วรรณกรรมเชิงนิเวศมากขึ้น บทความนี้ไม่เพียง แสดงให้เห็นความย้อนแย้งในสาระสำคัญเกี่ยวกับ การอนุรักษ์ธรรมชาติและการนำเสนอภาพสัตว์ป่า ในภาพยนตร์เรื่องนี้ แต่ยังพิจารณาในบทสรุปถึง ศักยภาพที่จะสร้างผลตอบรับในแง่บวกเกี่ยวกับ สิ่งแวดล้อมและสร้างความเข้าใจที่ลึกซึ้งยิ่งขึ้น เกี่ยวกับสัตว์ป่าและตัวบุคคลที่อยู่ใจกลางภาพยนตร์ สารคดีเรื่องนี้ด้วย

\begin{abstract}
The documentary film Grizzly Man (2005), directed by Werner Herzog, is of special interest among ecocritics and environmental advocates because it deals directly with the topic of wildlife depiction, conservationism and, above all the interspecies relationship between grizzlies and man. This article investigates five problematic elements of Grizzly Man as an ecological film: the wildlife documentary as a genre, the highly controversial figure of Timothy Treadwell who produced the original footage, the grizzlies in the background, the voice and hand of the director Herzog in this film, and the film's ending. The analysis of these five areas may deepen the audiences' understanding of both the film and the ecocritical approach to literature. Apart from highlighting certain contradictions in the film's ecological message and its representation of wild animal, the article tries, in its conclusion, to examine the film's potential to generate environmentally positive responses and create a better understanding of both
\end{abstract}


Of Grizzlies and Man

wildlife and the key human figure in this film.

\section{Introduction: Ecocriticism and Previous Criticism of Grizzly Man}

Ecocriticism $^{3}$, a recent branch of study that involves the analysis of the relationship between the environment and literature and art, has a keen interest in the depiction of nature, non-humans and, even, cultural values related to environmental issues. Consequently, Werner Herzog's Grizzly Man (2005), which deals directly with an advocate of bears and includes numerous depictions of wildlife, is among those works of interest to ecocritics. This documentary is primarily about Timothy Treadwell, an American bear enthusiast who spent the last thirteen summers of his life watching, studying and filming grizzly bears in Katmai National Park, Alaska, until he was attacked and devoured by a bear in 2003. His life story fascinated the internationally acclaimed director Werner Herzog, who was given access to Treadwell's footage and who interviewed several close friends of Treadwell as well

\footnotetext{
3 The oft-cited definition of ecocriticism is Cheryll Glotfelty's from The Ecocriticism Reader (1996: xviii). "What then is ecocriticism? Simply put, ecocriticism is the study of the relationship between literature and the physical environment. Just as feminist criticism examines language and literature from a gender-conscious perspective, and Marxist criticism brings an awareness of modes of production and economic class to its reading of texts, ecocriticism takes an earthcentered approach to literary studies."
}

as other individuals involved in his project. He then mixed all these materials with his own recording of the landscape and narrated as well as commented on Treadwell's life and work. The documentary film, therefore, can be said to include images and voices of both Treadwell and Herzog. In general, the critical reception of the film and the filmmaker was positive and reflects the complexity of Treadwell as an individual. For example, a film reviewer Peter Bradshaw (2006) of The Guardian, particularly enjoyed Treadwell's excessive theatricality and regarded the film as a tragicomedy_-"It is poignant, it is beautiful, and it is absolutely hilarious. Herzog didn't even have much work to do... because Treadwell—gifted, untrained film-maker that he was-had done almost everything himself... Poor Mr Treadwell. He loved those bears. And they loved him. Yum, yum!" Manohla Dargis (2005), a film critic of The New York Times offered a more compassionate evaluation of Treadwell's life. He wrote that Treadwell "traveled a familiar American path shaped by boundless optimism and an almost religious belief in the self" and in this film, interviewees seemed to "capture some authentic quality of Treadwell, who from the evidence of his videos and Mr. Herzog's sympathetic inquiry, seemed equally nice and naïve, brave and foolish."

As well as these film reviews, literary and film scholars have written about the film in terms of the characterization of the enigmatic central character, Timothy Treadwell, his complicated relationship with the bears, and Herzog's cinematic 
techniques and his tendency to depict animals in a politicized manner. This article aims to add to the existing debate by reappraising Treadwell-Herzog stories in terms of environmental film. Considering the five topics - of the genre as a wildlife documentary, the ambiguity of the main character Treadwell, the grizzly bears and its positioning, the voice of Herzog, and the film's closure-this film proves to be extremely ambivalent in terms of wild animal representation and protection, even though it still maintains some practical value as an environmental film.

\section{Wildlife Documentary: Wildlife! To see, perchance to film-ay, there's the rub}

Ordinary people do not often have a chance to encounter wildlife in its natural habitats. For the most part, our perception of wildlife derives from visual representation, especially from wildlife documentaries. Nevertheless, through modern, technological cinematographic manipulation, viewers may be unaware that by watching wildlife documentaries they are being exposed to a distortion and, sometimes, propaganda or, even, downright racism. As Greg Garrard's Ecocriticism suggests, there are various problems in wildlife documentaries, which I think can be summed up in four main categories: misrepresentation, sentimentalism, reduction and (non)narrator projection. In more detail, these problems include am overemphasis on wildlife sex and violence, a presupposition of animals' thoughts and feelings, a tendency to enforce social norms out of wildlife behaviours, the compression of time and simplification of people filmed, and seemingly neutral projection of an anonymous commentary (2012:173-6). All these inclinations are definitely present in both Treadwell's footage and Herzog's film; but I would rather focus on another aspect that probably escapes the audience of Grizzly Man and wildlife documentaries in general even though it is most relevant to animal conservation, that is, the representation of threatened wild animals and the people surrounding them.

In order to produce an hour of wildlife documentary, the production team must film an extended amount of footage and spend a long time searching for the targeted animals. If the wild animal is rare, the whole process gets more complicated; but even more troublesome is the fact that the animal must be shown plentifully in spite of its rarity. As a result, even when the director has a strong desire to inform and raise the conservationist consciousness of his audience, wildlife documentaries and films are often fraught with contradictory messages. They "carry the conservationist message that an animal is rare, but then depict large numbers of them. Absent animals do not make for exciting viewing" (Garrard 2012:175). As a result, the major environmental concern of extinction is very difficult to project or visualize in wildlife films. One might start by asking whether it is at all possible to represent the absence of animals or depict the threat of extinction powerfully in visual art. Even more challenging is how to engage a mass audience with non- 
Of Grizzlies and Man

thrilling, non-sentimental images of empty forests or oceans in an attempt to prove that certain species have been serious endangered. In this regard, the footage of Treadwell, too, convey mixed messages. He claimed to have devoted his life protecting grizzly bears, which are listed as endangered animals in the United States and Canada. Yet he did film a number of bears and as a result his footages fail to convey any sense of the threat to bears apart from his own invasion. Apart from that, bears are shown to starve and sometimes eat their own kind because of inadequate rainfall and fish in the stream, which seems to suggest that it is beyond humanity's ability to relieve them. Worse, Treadwell's sensational attempt to invoke rain by pleading with higher beings carries a less powerful message about the bears' suffering than about his own exaggerated desperation and eccentricity. Containing this original footages full of bears, Grizzly Man as a wildlife documentary film thus seems less convincing in raising concerns about the endangered status of grizzly bears.

The second problem involves not only the depiction of wildlife but also of people appearing in this film. It often happens that many wildlife documentary teams choose foreign territories on which to shoot wild animals, in which case tension between producers and people inhabiting the place is likely to be depicted as well.

The favourite location for wildlife documentaries is the African savannah with its 'charismatic megafauna' such as elephants and giraffes, where the camera sometimes seems to stand in for the colonial figure of the white game hunter. Despite the fact that Africans have coexisted with these species since ours evolved there, humans are either been totally excluded from the scene, or introduced in one of the two roles: destroyer or saviour. At worst, black hunters are the demonized as 'poachers' while white conservationists are valorised. (Garrard 2012:175)

A highly illustrative case of Garrard's statement can be found in Grizzly Man. In spite of the evasive racial and political differences, Treadwell projects himself in his footages as the protector of these animals and excludes park officers and other visitors as enemies and intruders. Among the people Herzog interviewed, only one is described with an ethnic identification "Sven Haakanson, Ph.D. I Alutiiq"." As curator of Kodiak's Alutiiq Museum, Haakanson describes the native people's way of life as being close to the grizzlies, but at the same time maintaining ample distance from the bears' community. "Where I grew up, the bears avoid us and we avoid them. They're not habituated to us. If I look at it from my culture, Timothy Treadwell crossed a boundary that we have lived with for 7,000 years." Even more than crossing the so-called boundary, Treadwell acts as if people always wanted to hurt the animals and were all potential poachers. $\mathrm{He}$

\footnotetext{
${ }^{4}$ Alutiiq is a native community of Alaska.
} 
describes the grizzly maze as a place "where bears do not have human protection, but are under human threat." What is ironic, perhaps, is the fact that Treadwell barely succeeds in convincing viewers of the threat, as well as of himself as the bears' saviour. His attempt to simplify people into two roles of destroyer and protector seems to be undermined by Herzog's interviews and selection of Treadwell's original footage. Each testifier seems well aware of the endangered status of the grizzlies; they do not want to hurt them. Treadwell, on the other hand, constantly violated the National Park's rules and was actually filming in a sanctuary where bears are protected and where, according to statistics, a stable, healthy population of grizzlies has been maintained as poachers are very rare in the region.

To conclude the topic of the wildlife documentaries' limitations, audiences should be reminded that despite their valuable task of bringing wild animals to our home, watching a wildlife documentary or movie is not necessarily the best way to understand wildlife or acquire a conservationist consciousness. By increasing the distance between viewers and the actual experience of wildlife, such works often reduce living, three-dimensional beings into wholly visual representations subject to our need for entertainment. As it turns out, the question of animal and human representation in Grizzly Man is rendered even more problematic as the filmmaker in this case is perhaps as unusual as the wild animals he filmed. This point will be elaborated in the next section.

\section{Timothy Treadwell: "I came, I served, I protected, and I studied."}

For those who have never heard of Timothy Treadwell before, the film does make clear from the beginning that it is dealing with a quaint, extraordinary bear maniac who introduces himself as a "kind warrior," a "samurai," and the "master" of the bears. While many of his friends and associates attest to his kindheartedness and genuine will to protect the animals, several interviewees successively question his sanity or his lack of commonsense. This section aims to analyze the way in which this man presents himself and the controversy surrounding him. This can hardly be done without addressing the opposing view of the director Herzog and his involvement in projecting Treadwell. So in this section I will try to discuss Treadwell's self-representation and mention Herzog's contribution only when it involves the younger man's controversial images. More arguments about Herzog's manipulation of Treadwell's footages will be discussed later in the section "Werner Herzog."

The film ecocritic Pat Brereton points out the fact that Treadwell's footages differs significantly from traditional wildlife programing even though it similarly includes beautiful wild landscape and wild animals. "The landscape is displayed... in Treadwell's conventional picturesque framing of a lake in the foreground and beautiful snow-capped mountains in the background. [But as Treadwell] walks into the static frame and begins ranting to camera, the viewer is invited to consider whether he is acting or just cathartically 
Of Grizzlies and Man

emoting as he performs for the camera" (2013:222). Indeed, the question of this man's motive probably arises in all viewers' mind. Margot La Rocque, a wildlife cinematographic scholar, elaborates on a number of reasons why people shoot wildlife pictures, such as the need to be out of doors, to contribute to science, or as Richard Kearton puts it, to "pit one's skill and ingenuity against the shyness and cunning of a wild beast" (qtd. in La Rocque 1991:36). The case of Treadwell, however, seems to fit $\mathrm{La}$ Rocque's most fundamental explanation"what prompts one to photograph wildlife? What is the urge? The desire to photograph a wild animal may be said to grow out of respect and affection for the species" (1991:36). Affection is obviously one of the reasons why Treadwell traveled into the heart of Katmai National Park every summer for thirteen years; but what lies beyond his love for animals is a shadow. What is the purpose of Treadwell's recordings? What could be the original aim of the footage? Treadwell did not seem to plan to make a real film of any kind; he was not actually a movie-maker or a director. On the surface, he claimed to record the beauty of the animals and nature in order to show them to school children and propagate a new and more accurate understanding about grizzly bears as harmless, peace-loving animals. Herzog, by contrast, tries to introduce the idea that Treadwell might only want to give himself the chance to star in a film, or even to confess-"to scrutinize his innermost feeling, his demons [and] exhilarations." All these are probable reasons behind his footage, but I would like to draw audiences' attention to the fact that
Treadwell probably did not intend to show all of his footage in such a way it is. Since it is done more for personal reasons, the footage is mostly incoherent and very personal. The fact that the whole length of his recording was not made primarily for public viewing is an important thing we should bear in mind before we judge him and judge what he says in front of the camera. In other words, Grizzly Man for the most part is composed of Treadwell's private world to which we are allowed access only through Herzog's selectionand partly manipulation-of Treadwell's original materials. Moreover, it should be observed that Treadwell seems to be interacting normally in certain scenes when he was not projecting himself as the star of his camera, for example, in the scene where he asks his girlfriend, Amie Huguenard, to let him carry the water from the helicopter and, especially, in the scene where he was being interviewed for a television programme.

As an ecocritic, I feel that the controversy surrounding Treadwell matters very much in this movie because it creates confusion about the film's environmental stance. Through Treadwell's self-representation and Herzog's attempted interpretation of this man's life pursuit, the film's ecological message is virtually overshadowed by anthropocentric interests. Drawing attention to his own stardom, Treadwell features in most of his footage because he claims to be in charge of his bear-friends. One of the most vivid illustrations of this case is when, at the closing of Expedition 2001, Treadwell asserts that he is "the only protection of these animals out here." It remains unclear 
what Treadwell has done exactly to "protect" the grizzlies. In fact, his utterance reminds me of Alan Root, the celebrated forerunner of wildlife filmmakers, when he concluded his film Lights Action Africa! - "Alan and Joan will go on filming, and will continue to share their wonderment and understanding. And who better to record, for all time, what used to be... in Africa?" (qtd. in La Rocque 1991:35). La Rocque then comments on the Roots' effort to save the animals simply by taking their picture. "The urge to save wildlife has been translated into the urge to record it: the preservation of a life by its representation" (1991:35) which can be turned into a commodity afterward. The Roots' activities and obsession, I believe, are applicable to Treadwell's. In spite of the fact that Treadwell helped found Grizzly People, "a grassroots organization devoted to preserving bears and their wilderness habitat" ("Grizzly People"), which established him as a naturalist and a wildlife activist; Herzog's chosen footage seems to suggest otherwise. In the second half of the film, it becomes clear that Treadwell was suffering from certain personal problems and anxiety and this drove him constantly into the woods. His past experience of drug abuse, failure at work, emotional disturbance and symptoms of paranoia, evident in his selfrecordings point to the fact that he might be seeking the company of bears and other wild animals in order to nurse his selfesteem. He seemed to seek acceptance, recognition, and meaning for his life both from those animals and from other people through his adventurous enterprise. Opponents of Treadwell's activities might also attack him by pointing out the fact that his behavior could have been a bad role model for others to imitate and that Treadwell was propagating a misconception about grizzly bears. His actions might have been of direct disadvantage to the bears because his presence habituated bears to humans and he was definitely intruding on the bears' activities unnecessarily. Thus, in spite of his claims about loving and protecting the bears and his role in organizing an animal activist association, Treadwell's actions under the banner of the environmentalist cause are extremely ambivalent and deserve criticism as well.

\section{The Beast in the Background: Imagining and Representing Non- humans}

In the promotional poster of the film, Treadwell is projected as standing up coolly to an enormous, growling grizzly bear. Indeed, one of the recurring images in the film is that of big brown bears loitering in the background of Treadwell's footage. In spite of being mentioned in the title of the film, the bears seem to function only as the enigmatic Other to Herzog and the audience. For all of Treadwell's determination to represent the bear as a friend and his saviour, Lisa Mighetto points out the paradox in the relationship between Treadwell and his bear-friends.

The irony of the film is that for all his years living with and studying grizzlies, Treadwell misunderstood these animalsand knowing his fate makes watching him interact with them a painful experience. "I'm in love with my animal friends," he 
Of Grizzlies and Man

tells the camera at one point. "I am one of them."... One disturbing shot shows him reaching out to a cub, which looks more dangerous than cuddly. And while he describes "Mr. Chocolate" as "my good friend," there is no evidence that this large male bear, hovering in the background with formidable teeth and claws, feels the same way. (2007:339)

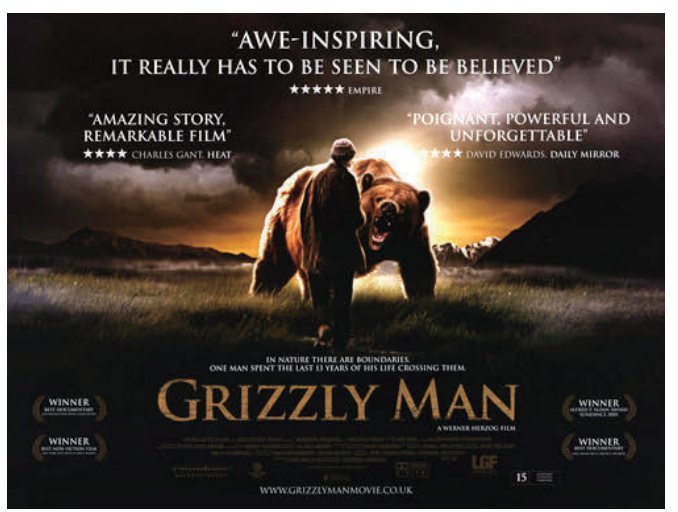

Figure 1: The promotional poster of Grizzly Man

In the field of animal studies, the question of animal agency has always occupied the stage. While it is never with in our ability to access or understand animals' mind, the tendency seen in most wildlife documentaries and films is that they are given certain human characteristics, whether positive or negative ones. Besides calling a grizzly bear Mr Chocolate and a good friend, Treadwell does show overdramatic instances of anthropomorphism when he addresses a couple of male bears as Sergeant Brown and Mickey, fighting for "the right to court Saturn, the queen of the Grizzly sanctuary." Treadwell, assuming the role of an excited sports commentator, gives a lengthy comment afterwards-“"Here I am at the scene of the fight. It looks as if tractors tore the land up... There is fur everywhere, and in the camera foreground excreted waste. In the middle of the fight, so violent, so upsetting that Sergeant Brown, um, went to the bathroom, did a number two during his fight." Treadwell's comical description that betrays his perception of a non-human as a fellow human being lays on him the charge of downright sentimentalism. Even so, in contrast with Treadwell's view, the bears in other people's understanding are simply mechanically perceived. Greg Garrard, for example, suggests that if Treadwell's weakness is crude anthropomorphism:

Herzog's rhetoric of animality is mechanomorphic, reducing the bears to instinctual machines: commenting on a close-up of the face of the bear that may have killed Treadwell, he argues that 'there is no such thing as a secret world of the bears, and this blank stare speaks only of a half-bored interest in food.' But then he criticises Treadwell's grief over the death of a baby fox: 'I believe the common denominator of the universe is not harmony, but chaos, hostility, and murder.' Clearly terms such as 'murder' and, elsewhere, 'fornication' are every bit as crudely anthropomorphic as Treadwell's rhetoric of 'love' between species. (2012:156)

Despite Garrard's criticism, it remains extremely difficult to avoid Treadwell's 
anthropomorphic and Herzog's mechanomorphic representation of animals and seek more neutral terms, the existence of which I believe are open to debate. What should be noted is that in the same vein as Herzog's seemingly objective perception of animals, the authority usually categorizes wildlife in the least human terms. While Treadwell has given his bear-friends names, such as Mr Chocolate, Ed, Rowdy, the Grinch, Sergeant Brown and Mickey, with the hidden implication of claiming acquaintanceship with if not possession over them, these bears are known to the park service by numerical identifications. The bear that probably killed Treadwell, for one, is known as Bear 141. Herzog describes this old male bear simply by saying, "Bear 141. That's all we know of him." Such a minimal claim to know anything about an animal might sound rational to most people but, in fact, it is still a dangerous reduction of living entities to machines or objects devoid of any emotion or unique quality. Therefore, the question remains not only whether animals are capable of feelings or have intellect but also how far our different modes of representation that range from crude anthropocentrism to mechanomorphism-which for the most part we are not aware of - are, actually, downright misrepresentations. In other words, sundry labels for wild animals, whether friends, murderers or saviours, in this story and elsewhere, should always be regarded with caution.

The fact that bears appear mostly in the background of this film and of Treadwell's footage should also prompt a re- orientation in our thinking. This leads me to another important issue regarding animals - their rights and protection. What seems to have completely slipped other critics and scholars' attention is the fact that the bears suspected of being the killer of Treadwell and his girlfriend, Amie Huguenard, were finally hunted down. According to Willy Fulton, Treadwell's friend who was present on the hunt, the bear was "shot in the head and the neck and everywhere." The question that has never been raised, understandably due to the ethical assumption that prioritizes human life over animal, is whether it was necessary and fair for the bears to be so horribly executed, in spite of being a protected animal and in spite of acting out of hunger in their own territory. Moreover, the incident, tragic to the bear as well as to Treadwell and his girlfriend, should compel us to rethink whether Treadwell's project could be said to have done more good than harm to both parties, humans and the non-humans.

\section{Werner Herzog: The Voice is in the Air}

In spite of the title and the opening of the film with Treadwell speaking in front of the camera and with a mature grizzly in the background, the succeeding parts of the film are largely accompanied by Herzog's voiceover commentary. It is important that viewers bear in mind that the film, though wholly about Treadwell and including much of Treadwell's footage, is primarily Herzog's art. Out of more than a hundred hours of wildlife and Treadwell's self-shot footage, only about one percent was chosen by the senior director. Often Herzog takes pains to 
Of Grizzlies and Man

interpret Treadwell's messages or guess his intentions. When Treadwell pets a fox and pleads with the audience not to hurt or hunt these foxes, Herzog concludes, "Timothy used his camera as a tool to get his message across." Some of the selected footage is extremely repetitive as Treadwell did a number of takes to get the perfect recording; but Herzog chooses to include it all to emphasize Treadwell's intention to "craft his own movie" and possibly to point out the young man's absurdity. Beyond these obvious interpretations of the director are some more indefinite, daring conclusions. In the middle of the film, Herzog explains that Treadwell did confess to his preference of the bear's world over human society in his diaries. With long shots over the vast expanse of glacier, full of sharp, piercing ice columns and crevasses, Herzog's dispassionate voice drifts in, "Wild, primordial nature was where he felt truly at home... This gigantic complexity of tumbling ice and abysses separated Treadwell from the world out there. And more so, it seems to me that this landscape in turmoil is a metaphor for his soul." Obviously, this is Herzog's effort to get into the heart of Treadwell and to represent it visually, using the wild, empty landscape of ice, most detached from any human presence, to signify Treadwell as Herzog imagines him to be.

The question that arises is whether or not Herzog is trying to romanticize and mystify his subject of study, in exactly the same way as Treadwell did with his bears. On the one hand, Herzog's voiceover commentary might remind us of a traditional documentary narrative style.
This transforms Treadwell into an animal under Herzog's close observation. In other words, the film seems to serve as the study of a human being, with bits and pieces of recordings and a number of interviews to piece together the mystery - the troubled, complex psyche of this individual. On the other hand, while trying to get to the heart of Treadwell, Herzog's omnipresent voiceover and his manipulation of the footage, the cutting and the editing to create tension and suspense, help craft or rather carve out Treadwell as a person. Previously, Treadwell had been known generally only as "a wildlife author... known for approaching, even touching, bears in the wild" according to his obituary in The Telegraph ("Final Cries" 2003). Yet in this film, Treadwell is conjured up and even re-created by the director Herzog, who gives his life and works actual substance and who explores the darker, lesser-known facts about the young man. During this process, it is clear that Herzog, too, reveals himself and his opinions about Treadwell and what the younger man lived for. At first he openly admires Treadwell for the footage - at the image of the tent's roof trodden by a fox filmed from the interior, Herzog declares, "I, too, would like to step in here in his [Treadwell's] defense, not as an ecologist, but as a filmmaker. He captured such glorious improvised moments, the likes of which the studio directors, with their union crews, can never dream of." Indeed, the film alternates with glimpses of natural beauty, spontaneously captured by the hand of Treadwell. Oleg Gelikman, in addition, says that "even though the Grizzly Man never made his film, Herzog pays Treadwell the filmmaker a handsome 
compliment and contrasts his footage with the ordinary wildlife documentary" (2008:1057). Herzog's further comments about Treadwell's doings, however, are not wholly in agreement.

While it is interesting to observe that Herzog's voice-with its characteristic depth, clarity and neutral elocutionist style-seems such a contrast to Treadwell's superfluous and high-pitched expressions, it becomes clearer toward the end of the film that the senior filmmaker differs from the young bear enthusiast at a fundamental level. In at least two scenes, Herzog directly exploits the footage of Treadwell, turning it, quite openly, against the young creator. The first scene is only a few minutes into the film, when Herzog shows the image of Treadwell playing and trying to pet the bear he calls Rowdy, with slow, intriguing music running in the background. Suddenly the music stops as the bear abruptly lurches at the camera, jerking us back to reality and reminding us of the danger of these animals against Treadwell's attempt to befriend or romanticize them. In another scene towards the end of the film, Treadwell is irate with the Park officers and the Park restrictions. He shouts, "Fuck you, motherfucking Park Service!" right into the camera. While the image of Treadwell is running, making rude gestures against those park authorities, Herzog's voice interferes and drowns out Treadwell's voice completely. "Now Treadwell crosses a line with the Park Service, which we will not cross. He attacks the individuals with whom he worked for 13 years." The interference of Herzog's voice is, to me, proof of two contesting views, not only about the Park Service but also about nature and animals in general. Lisa Mighetto suggests that "it seems clear that he [Treadwell] romanticized the bears, while Herzog sees indifference rather than kinship in the natural world. Herzog's is the dominant view here-and Grizzly Man shows the terrible consequences of misunderstanding the natural world and assuming a benevolent bond that does not exist" (2007:340). Similarly, Pat Brereton opines that "Herzog frames Treadwell's footage with commentary and interviews that serve as a critique of the "deep ecological"5 manifestations of harmony with wild nature" (2013:221). So much is obvious, but what many people seem to forget is how Herzog's representation of the non-human is not impartial and thus should not be commendable, either. It is true that Treadwell's stance on animals and the environment is anthropomorphic, overtly romanticized and dangerously extreme, but Herzog's contesting view about nature is dispassionate, unfeeling and unsympathetic, in spite of being perfectly rational. The film seems to portray Treadwell as a genuine nature lover with good intentions, but rather quaint, naïve, and slightly annoying; while Herzog seems, in contrast, much more

5 Deep ecology is a radical form of environmentalism that believes in the intrinsic value of nature, regardless of its usefulness for human purpose. According to its founding philosopher, Arne Naess, deep ecologists insist that "the well-being and the flourishing of human and nonhuman life on Earth have value in themselves" and that "the flourishing of nonhuman life requires a smaller human population" (qtd. in Garrard 2012:23-4). 
Of Grizzlies and Man

mature, fair-minded and understanding. For these reasons, most audience might opt for the director's stance on environmentalism rather than Treadwell's. However, so far the problem with Herzog's idea of environmentalism remains vague, will I try to get to the heart of it in the last section, which discusses the concluding scenes of the film.

\section{The Film's Ending: "Not so much a look at wild nature"}

Towards the end of the film, Treadwell's three close friends travel to his camp site in the Grizzly Sanctuary to scatter his ashes, a sentimental and trite operation that nevertheless signifies respect and the peaceful culmination of Treadwell's life. Afterwards, Herzog concludes the film with images of bears running in the wild, a summation of his work, and a beautiful folksong "Coyote ${ }^{6}$." Here we are compelled to review the role of nature, one of the primal interests of ecocritics, that is reflected in this artistic work. Throughout

\footnotetext{
${ }^{6}$ Coyote, a wild animal native to North America, carries both cultural and ecological significance. The coyote "figures prominently in the religion and mythology of a number of Native American tribes" (Cooper 1987:182) as well as in Native America literature, such as in Simon Ortiz's poem "The Creation, According to the Coyote." In terms of ecological significance, coyotes are important to the ecosystem as natural predators of rodents, rabbits, and birds. However, a recent expansion of coyote population has resulted in a threat to domestic animals and livestock. This has triggered an attempt to control the coyote population and, in certain areas, blanket extermination (Feldhamer et al. 2003:475-6).
}

the film, with the focus on the central character Treadwell and the voice of the Herzog that serves as the commentatormaster behind the curtain, nature is reduced only to a backdrop for the main character's fascinating project and tragedy. Not much better than the landscape, the beasts are, as I argued earlier, always securely kept in the background. In spite of having a significant part in the title and the commercial representation of the movie, the "Grizzly" serves only as a signifier of "Man" and as a prop against which the sole hero fearlessly stands. All these details are confirmed by Herzog's concluding words. Speaking in a rather resigned tone, the director sums up his work:

Treadwell is gone. The argument how wrong or how right he was disappears into a distance, into a fog. What remains is his footage. And while we watch the animals in all their joy in being, in their grace and ferociousness, a thought becomes more and more clearthat it is not so much a look at wild nature as it is an insight into ourselves, our nature. And that, for me, beyond his mission, gives meaning to his life and to his death.

In contrast to Treadwell's original intention, to educate the mass and rectify people's misunderstanding about the grizzlies, Herzog finally declares that Treadwell's footage does not actually serve that purpose. Instead, he claims that this footage helps us recognize or understand ourselves and our nature. The 
problem, of course, arises as to whose self he is referring to. Does Herzog mean that watching Treadwell's films will bring us closer to an understanding of ourselves as individuals or humans in general? Could it be that by looking into the bear's eyes, be it love-filled or vacant or ferocious, we come to know ourselves better, as a species distinct from them? Does this apply to Treadwell who deemed the bears as his saviour and tried to find a meaning to his life by watching and filming them? Do we get to know our place in the world in relation to the animals; or perhaps realize more about the possible, similar irrationality of human beings and animals in Treadwell? The answer probably depends on each viewer. One insightful interpretation of the film's core message that I have come across is from Oleg Gelikman, who has come to reflect on our general callousness and lack of compassion for non-human beings around us:

Despite the crudeness of Treadwell's theatrics, we cannot help but be impressed by the distance his understanding seems to have traversed. We feel guilty and amazed at our own unwillingness to imagine such capacious modes of empathy. We are awed by the dignity he is capable of bestowing on the world around him and wounded by our habitual refusal to do the same" (2008:1151).

On a different ground, the footage of Treadwell and Herzog's re-interpretation of them seem to me a plea for an understanding, not only for the bears but also for Treadwell. It supplies information and controversial opinions about this man, then challenges us to try to understand and, if possible, to have compassion for this quaint and deeply troubled person. This conclusion comes to me with a sense of sadness and mourning for Treadwell and is underlined by the closing song. Don Edwards, an American cowboy singer and guitarist, re-performed the old song "Coyotes" as a tribute to Treadwell. The sad tune goes well with the lyric-

Now the long horns are gone. And the drovers are gone.

The Comanches are gone. And the outlaws are gone.

Geronimo is gone. And Sam Bass is gone.

And the lion is gone. And the Red Wolf is gone.

Acutely nostalgic, the song mourns the loss of important outlaw figures, some Native American freedom fighters, as well as some plants and animals that have disappeared. Since the pilot who sings along in the film replaces the words "red wolf" with "Treadwell," the young man, also an outlaw in a sense, is clearly elevated as his name is sung along with those renowned figures. In the second verse of "Coyotes," the protagonist "cursed all the roads and the oil men, and he cursed the automobiles," which can be seen as an outright rejection of civilization and modern society. His disappearance at the end of the song, while only the howls of the coyotes remain, helps highlight how Treadwell was a sort of a social misfit who felt more at home with the forest and wild 
Of Grizzlies and Man

animals, the passing world of harmony between humans and non-humans. The song can also be said to carry certain ecological messages even though it is culturally embedded to some extent because of the reference to various American native species and historical figures. Thus, even as Herzog rebukes Treadwell for his naïve perception of nature and his over-romantic tendency, it turns out that in the end the director falls for the same sentimental rhetoric and laments, albeit indirectly, the loss of Treadwell along with the loss of the natural world through this song.

\section{Conclusion}

Due to the problematic nature of wildlife documentary, the enigmatic, prattling self-publicist as the main character, the depiction of animals as a backdrop and the obscure environmentalist concern of the filmmaker, Grizzly Man seems to fall short of nature and the expectation of animal advocates in spite of the promising and dominant issue of wildlife conservation. On the contrary, nature, animals and landscape are presented only as agents supporting anthropocentric interests, both for Treadwell and Herzog. Of the two men, Herzog seems to have much less to say on behalf of the grizzlies. Since his focus is not on the bear but the man who went to live close to the bear, the film does not directly serve conservative purposes. Nevertheless, this should not render the movie totally worthless from the ecocritics' point of view. This documentary film can still be a valuable study of how nature and animals have been utilized by filmmakers to hog the limelight at the expense of the charismatic but silent non-humans, that are usually seen as a fascinating yet alien species. Also, the fact that the film director has no intention of making the endangered species the top of his agenda does not mean that his product is be totally incapable of generating environmentally positive responses. First, this film can make viewers feel more skeptical with Treadwell's enterprise and underlines the "boundaries," either in terms of interspecies difference or geographical territory. In consequence, audiences may feel that they should let wild animals live with minimal human interruption and this would be better for them in general. Apart from that, viewers might appreciate the beauty of the beasts and the sublime landscape in the footage, both of which might develop into a strong public desire to protect the species and their habitat. Also, Treadwell's genuine commitment to the bear may yet inspire the conservationist consciousness through the ongoing movement of Grizzly People, which definitely benefits in terms of publicity from the movie. Thus, even with the film's ambivalent representation of nature and non-human species, Grizzly Man is still an invaluable work that informs us about grizzly bears, shows us their extraordinary beauty and brutality, and inspires us to reflect about the life, strength and vulnerability of a fellow human being. Grizzly Man, as its title suggests, is not only about the grizzly or the man, but a mixture of both; and in spite of certain flaws as an ecological film, it still brilliantly prompts us to respect both the animal and the man-for we learn to respect its territory and its 
right to live apart from us, and the for other his ultimate compassion and commitment to beings so different from himself and us all.

\section{References}

Bradshaw, Peter. 2006. Film Review of Grizzly Man. 3 February 2006, The Guardian. May, $19^{\text {th }}, 2015$

$<$ http://www.theguardian.com/ culture/2006/feb/03/1>

Brereton, Pat. 2013. Appreciating the Views: Filming Nature in Into the Wild, Grizzly Man, and Into the West. In Ecocinema Theory and Practice, edited by Stephen Rust, Salma Monani and Sean Cubitt, pp. 213-231. New York: Routledge.

Cooper, Guy H. 1987. Coyote in Navajo Religion and Cosmology. The Canadian Journal of Native Studies VII.2: 181-193.

$<$ http://www3.brandonu.ca/ Library/cjns/7.2/cooper.pdf>

Garrard, Greg. 2012. Ecocriticism. $2^{\text {nd }}$ edition. Cornwall:

Routledge.

Dargis, Manohla. 2005. Film Review of Grizzly Man: Exploring One Man's Fate in the Alaskan Wilderness. 12 August 2005, The New York Times. May $19^{\text {th }}, 2015$
$<$ http://www.nytimes.com/ 2005/08/12/movies/12griz. html?_r=1\&>

Final cries of couple killed by bear. 10 October 2003. The Telegraph. May, $20^{\text {th }}, 2015$ $<$ http://www.telegraph.co.uk/ news/worldnews/northamerica/ usa/1443788/Final-cries-ofcouple-killed-by-bear.html>

Feldhamer, George A., Bruce C. Thompson and Joseph A. Chapman. 2003. Wild Mammals of North America: Biology, Management, and Conservation. Maryland: The John Hopkins UP.

Gelikman, Oleg. 2008. Cold Pastoral: Werner Herzog's Version of Empson. MLN: Comparative Literature Issue 123.5: 1141-1162.

Glotfelty, Cheryll. 1996. Introduction: Literary Studies in an Age of Environmental Crisis. In The Ecocriticism Reader: Landmarks in Literary Ecology, edited by Cheryll Glotfelty and Harold Fromm, pp. xv-Xxxvii. Athens: University of Georgia Press.

Grizzly People: Home Page (n.d.). Grizzly People Inc. May $20^{\text {th }}$, 2015 $<$ http://grizzlypeople.com/ home.php> 
La Rocque, Margot. 1991. Domination and Preservation: Reflections on Wildlife Cinematography.

Undercurrents 3: 33-39.

$<$ http://currents.journals.yorku.ca/ index.php/currents/article/viewFile/ 37928/34395>

Mighetto, Lisa. 2007. Going Wild: Never Cry Wolf and Grizzly Man.

Environmental History 12.2: 337-340.

Nelson, Erik (Producer), \& Herzog,

Werner (Director). 2005. Grizzly Man. United States: Lions Gate Films. 